\title{
MILAN ZLOKOVIĆ AND THE PROBLEM OF PROPORTIONS IN ARCHITECTURE
}

\section{A B S T R A C T}

The main theme of the article is the analysis of the contribution of Milan Zloković within the field of proportions and modular coordination, the themes he has been dealing with during a thirty years long period. Particular emphasis has been placed on Zloković's mathematical-geometrical approach and methods as well as on the conclusions made by him based on the rich builder experience and the results of the detailed analyses in the search for the original proposal of application of the system of proportioning in architecture, preferential numbers and ideal design modules. In this article an attempt will be made also to clarify and bring closer the manner in which Zloković arrived to the conclusions that certain proportional systems were of greater significance for the architectural composition than some other ones and also in which manner they are applied in the designing process, independent of style. Finally, a wider survey of the manner in which Zloković stands out in respect to some of his contemporaries dealing with the same theme has been provided. 
In his theoretical work, in the period from 1947 till his demise in 1965, Milan Zloković published around thirty publications on the topic of proportions and modular coordination in the Serbian, French, Italian and Macedonian languages. Almost all Zloković's papers analyze the application of proportions in architectural design and the systems of standard measures within the modular coordination as their central problem. The topics of study were: proportional systems of the past and the anthropomorphic systems of measures, preferential modular numbers and modular network. Measures and numbers (combinations).

As Aleksej Brkić recalls from their discussion in his book Znakovi u kamenu (The Signs in the Stone), Zloković would arrive to the solution simply by his feeling for breaking down one condition into the consecutive one ${ }^{1}$, however, that later on it became clear from his theoretical works that he could not have been satisfied with such subjectivized means. Zloković decided to seriously approach and work on the "objectivization of the sensitive practice" as soon as he had completed the solutions regarding the Pediatric Hospital in 1993, started as early as in 1933.

The two periods of his life and work, the pre-war and post-war (practical and theoretical) ones are often divided by Zloković's biographers ${ }^{2}$ into separate, independent wholes. However, in her book Elusive Margins of Belgrade Architecture 1919-1941, Ljiljana Blagojević, pays particular attention to the synthetic analysis of Zloković's work and claims that in order to understand Zloković's architecture in full, his practice and theoretical work have to be perceived as a unity.

Owing to the proportional analyses of the architect Ljiljana Blagojević in the book Modernism in Serbia: the Elusive Margins of Belgrade Architecture, it has indisputably been proved that even before he devoted himself to the theory of proportions, Zloković had intuitively used the regulative traces and geometrical systems for forming his modern houses and villas, in the period 1927-1932. ${ }^{3}$ In his article Anthropomorphic Systems of Measures in Architecture, dated 1955, Zloković himself noticed that before his theoretical research, he had intuitively applied the dimensions of the space of classic proportions ( 4:3 quarta and 5: 4 terza) in one design dated 1935.

Like the majority of the modern architects of his generation, Zloković had an excellent knowledge of modern architecture. His education and knowledge of the classic style orders are most likely indirectly responsible for understanding 
the significance of proportions for architecture. The ideas he acquired by becoming familiar with the classic architecture, he would introduce into the modern architecture by critical perception, as per his own sensitivity and estimation, claiming that it was actually the science on proportions which should be studied within contemporary architecture being the science of key significance for its further development and progress. He arrived to that idea in practical work, always critically accepting either the standpoints of the classic architecture or of the modern one. It is important to mention that in his researches Zloković confirmed that standpoint of his several times, which in the conclusion of his analyses he upgraded to the level of the statement, that the law of the uninterrupted division or "the golden section" was the only proportional system that each person gifted by creative capabilities intuitively aspired to. ${ }^{4}$ It is exactly on this system that Zloković's architectural compositions were based from the period he had not actively dealt with the proportions, but which he proportioned according to his feeling for the beautiful and the functional. ${ }^{5}$

Le Corbusier himself, who significantly influenced Zloković's formation as an architect said: "The proportional diagram is the pleasure of spiritual nature leading to the research of spiritual solutions and harmonious relations. It provides the eurythmics (...) The selection of the proportional diagram is one of the decisive moments of inspiration, one of the main actions of architecture". 6

In the above mentioned book, Ljiljana Blagojević, the author, has demonstrated that in the case of Zloković, harmony and proportion are an inseparable part of his designs, and not something added subsequently. For him, geometry and proportion are inseparably linked to the very architecture. Even though using the mathematical accuracy of the proportional diagrams, the artistic character of his opus remains irrevocable. In all his works, Zloković himself, emphasized that the use of proportion needed not mean the compulsory limitation of the architect in the creative expression. To support his standpoint, he would refer also to his distinguished contemporaries who had demonstrated the same standpoint in their work: August Perret, Frank Lloyd Wright, Le Corbusier, Mies van der Rohe.

As stated by Branislav Milenković, Milan Zloković gathered around himself a small group of his students, later on the associates as well, in the research of proportions and standard measures. However, the majority of these authors was later on predominantly engaged in the historical aspect of theory of proportions and coordinated modulation, so that Zloković had no real successors in this field. 
Each system he was introduced to, would be interpreted by him as proportional geometrical set or proportional numerical table, namely geometrical figure and number. He would draw himself the proportional schemes. Control diagrams and tables. However, he would not definitely a priori become attached to any system or reject it. He perceived the quality and limitations of each individual proportional system, owing to his dual approach to the problem: geometricalmathematical and practical-designer and almost each analysis was presented on his own example of contemporary design solution for the purpose of easier understanding of the manner in which previously analyzed system was the easiest practically applicable one.(Fig. 1).

In proportions he saw the aesthetic value as well, but from the engineer's point of view, also the simplicity of solution which diverse proportional systems provided each in its own way. Proportions in his work were not the goal per se but a part of the design method: "Proportionality has so often been taken for the goal in architectural design, instead as the means for achieving the composition."

The problem of the building module which Zloković sought exclusively among the anthropomorphic systems of measuring the past (being the only acceptable one unlike artificially created metric system ${ }^{7}$ ), is followed by his search for the preferential numbers required in the application of the selected module. A sequence of preferential numbers serves to proportionally chain up the relations of modularly dimensioned elements in the architectural composition of a certain building. Even though initially these two problems are perceived separately, only together do they provide practical solutions within the frame of the ultimate, most complex Zloković's field of research the modular coordination.

Studying almost all known proportional systems and compositional methods of the past, Zloković studied the Egyptian canon of measures, Plato's Timaeus and Lambda, Parthenon, ancient calipers with four legs with fixed proportional relation, style orders as per Vignola, Alberti and Caramuel, proportional systems of Palladio and Serlio, proportional systems of Fra Luca Pacioli, methods of proportioning of Fraçois Blondel, civic architecture, systems of measures and compositional methods of the ancient masters in Dalmatia, the theoreticians of the nineteenth century, however, also the contemporary architects or theoreticians who were distinguished within this field: Matila Ghyka, Ernst Neufert, Le Corbusier and many others the papers of whom he could come across. 
The last Zloković's written paper in Italian, Coordinazione modulare was published in Bari in 1965, the same year he passed away, presents the valuable collection and review of all his published and non-published researches and discoveries in somehow summarized form. ${ }^{8}$ This text was published together with the papers of another some ten authors, the experts predominantly from within the building industry in the publication under the title Industrializzazione dell'edilizia (Building industrialization). At the cover page there is Zloković's graphic display of the gradual division of the basic design module into 2, 3 and 5 equal parts, namely the division on the basis of the preferential coefficients which he himself suggested as the most convenient ones (Fig 2.) Thus he was given the deserved recognition also by the international experts, owing to his contribution in yet another field - the building industry.

\section{THE EXAMPLES OF THE APPROACH TO THE PROBLEM OF PROPORTIONS IN ARCHITECTURE OF THE MODERN MOVEMENT}

The interest in proportions emerges in the twenties as an idea which is opposed to the strict rules of academism, at the transition of styles, finding the ideals in the art of painting of that time, resisting the repetition and imitation of the master-pieces of the past, opening new vistas for innovations, researching plastics and introducing geometry into forms creation. As stated by Léandre Vaillat, they turned towards « the cold beauty», however «Intelligent» one which makes it possible to move further on, as it ensured greater certainty, and «tamed the fantasy» of the architect. Same like the art of painting of that time, architecture reverts to the aesthetics of geometry, tends to distance itself from individualism of the nineteenth century, and is derived from the wish «to introduce order into chaos» (Léandre Vaillat), and again seeks «the lost law» in the exact science: with the numbers and regulative traces (tracés
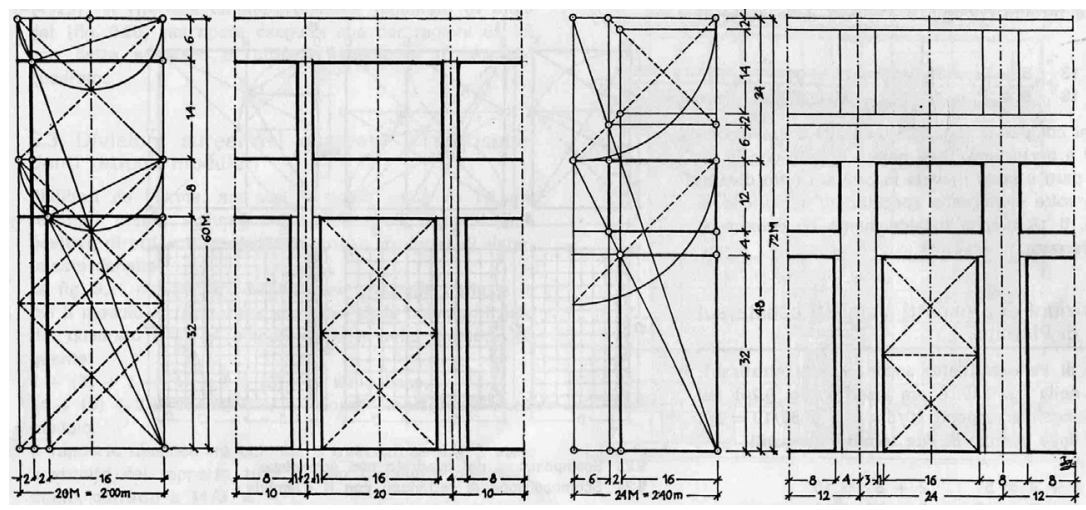

Figure 1

The sector of façade layout obtained by application of Plato's Lambda and harmonious system 
régulateureswhich bring rhythm into architecture. In his book on architecture in France from 1918-1950, Gérard Monier stated that the French architect Robert Mallet-Stevens (1886-1945) was one of the first practical followers of application of the regulative traces in designing, using them as control means of division on facade. His theoretical work remained in the shadow of Le Corbusier, and is left to be better examined. Another French architect from that period, André Lurçat (1894-1970), in proportions saw «the laws of harmony» and in his theoretical work noted that the classic style orders were unusable in contemporary architecture, but that they could prove useful in developing «rational aesthetics». ${ }^{10}$

Even though Zloković stayed in Paris for the professional training in the period from 1921 till 1923, according to his biographer, Zoran Manević. “...there were no data that in Paris Zlokovic moved in the circles of the modernists, nor that he was inclined to unreservedly accept their ideas; that, among other things, is demonstrated also by the first designs prepared upon his arrival in Serbia which were fully academically conceived."

In some of the significant Zloković's designs, the visual art language of the Italian rationalism is visible and in several works of the present researchers of Zloković's opus it was accentuated and analyzed in depth ${ }^{11}$, but same as regards the connection with the French modernists, Zloković's knowledge of the works of the Italian contemporaries cannot be stated with certainty, even though according to himself he often stayed in Italy between the Two Wars. However, it can be stated with certainty that the origin of the interest and the context in which the individual distinguished representatives of the Italian rationalism used the systems of proportions in their designs, differ substantially in relation to Zloković's ideas.

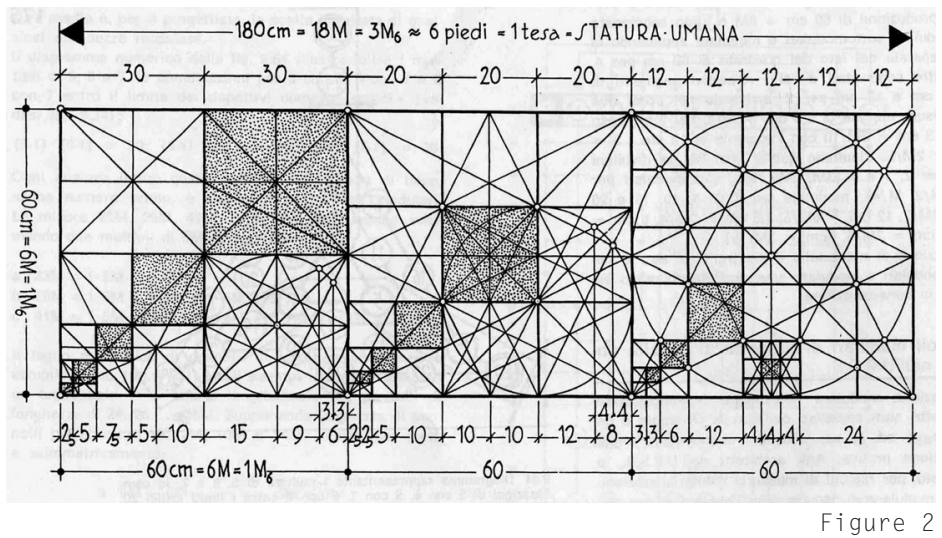


Giuseppe Terragni (1904-1943). Giuseppe Terragni was one of the prime movers of the Italian rationalist movement in 1926. In her book, Ljiljana Blagojević mentioned that among the photographs of carefully selected examples which Zloković had showed to his students she came across one residential building in Milan, the joint design by Terragni and Pietro Lingeri as well as the famous Casa del Fascio in Como.

One of Terragni's last unrealized designs, Danteum in Rome (1938-1940, together with Pietro Lingeri), is considered one of his best works, which in the best way depicts the author's talent and knowledge. Terragni's motifs and the manner of application of proportions in design can be studied in this example in an excellent way. As explained by Terragni himself, by using the golden rectangle, he wished to achieve more closer link with the adjacent Basilica di Massenzio, using the minor side of the basilica golden rectangle as the mayor side of the gold rectangle of Danteum. This way it becomes added to the adjacent architecture of the ancient Rome. Therefore, it does not only concern the aspect of form but also the number as the non-material element of architecture which creates impalpable links. Thus, Terragni is closer to Plato's idea of mystification of proportion than to the modernist idea of le Corbusier and his followers (even though Le Corbusier himself often favored philosophical arguments, having had no other explanation).

The use of the golden section and proportions was taken over as the sign of respect of the great works of the past, relying on their values more towards the religious beliefs and inclination to esotericism, than critically towards the significance of proportions for architecture in general. According to T. Schumacher, he created more of an elite architecture, mystical and full of hidden meanings and symbols than he wished by dimensions and the number, like Corbusier, to attempt to create a measurable architecture. In the golden rectangle, first of all he sees a symbolic significance. Terragni himself, in his text Relazione explained that the golden rectangle was a form often present in the works of the ancient Assyrians, Egyptians, Greeks and Romans, in the architecture which he himself wished to come closer to. $\mathrm{He}$ emphasized significance, myth and symbol as key words which describe the design (significato, di mito, di simbolo), which again incorporates the number 3 , the number which he assigned great significance to. ${ }^{12}$ Terragni reaches the proportion in an empirical way, by mystifying the origin of beauty. However, with his tendency to come close to his ancient paragons, Terragni also like Zloković expressed his admiration for beauty which he had not tried to fathom from the practical builder side, but by the empirical search for the beautiful and 
"sublimed", which actually are only the other terms for the calculated, after all, rational architecture. On the other hand, Zloković did not miss a chance to study the architecture of any of the above mentioned ancient civilizations, however, not looking for the mythological and religious meanings but design methods of the ancient builders owing to whom their works give out the beauty. Same like Cesare Cattaneo, Terragni gives preference to the circle and rectangle as the most significant geometrical figures.

The Italian architect Cesare Cattaneo (Como - 1912, Como 1943) who by his works marked the Italian rationalist architecture of the twenties and the thirties, in the spirit of the time in which he created, demonstrated the interest in the search for practical applications of the golden section in design. In his case as well this interest originated from the Neo-Platonism ideas typical for the Italian rationalists, inclination to metaphysics, esotericism and symbolical interpretation of the irrational numbers and the popularity of the new for that time, intriguing work of Matila Ghyka, Nombre d'Or, published in 1931. Cattaneo was a Catholic, so that for him the search for "the perfectionism of plastics" also had a not insignificant religious significance.

The motives for dealing with this task should be sought in Neo-Platonism ideas and metaphysical ideas and symbolic significance which the Italian rationalists attached to the irrational numbers, with a special emphasis on the number $\Phi$, due to its unique characteristics. ${ }^{13}$

Althoughasperhisownstatements, Cattaneodidnotknow thefield ofmathematics sufficiently in order to make more serious contribution to architecture in that field, ${ }^{14}$ as stated by him "for months he has been passionately dealing with" impossible problem of establishing the geometrical connection between the golden section and the circle (not knowing in the beginning for the mathematical proof of non-existence of squaring the circle). To which extent Cattaneo was occupied with this problem is evidenced by the pages and pages full of sketches and calculations which preceded this article. The procedure and the result of this research was presented in the article " $\pi e \varphi$ ", in which he explained the plausible solution which he arrived to and "its practical significance for simple approximate calculation of the circle square which could be interesting for the engineers, architects, surveyors and all those who would be satisfied with the approximate value of the required square area rounded to only two decimals."

Following his enthusiastic presentation of discovering the practical application of his formula, he revealed his regrets that his proposal 
of the formula meeting the requirement of "the principle of efficiency" in architecture remained unacceptable for the science, blaming his naivety for it.

However, like Corbusier who learnt about the mathematical error in the thesis of Modulor ${ }^{15}$, his failure and false belief of the impossible search for squaring the circle (the relation between $\pi$ and $\varphi$ ) Cattaneo, in an inspired manner, compared to the imperfection of the very architectural work and absurdity of seeking the absolute truth. These revelations float in-between the science and the empirical analyses. Their geometrical and mathematical inaccuracy makes space for the philosophical interpretations which lead to further mathematical discoveries, and until then one should not give up the facilitations such discoveries provide. Neither Le Corbusier nor Cattaneo would not give that up, however the applicability, most likely due to those errors exactly, was rather limited in their architectural opus.

THE CHARACTERISTICS OF THE RESEARCH PROCEDURE OF MILAN ZLOKOVIĆ: THE APPROACH TO THE PROBLEM AND METHODS OF RESEARCH

Already in the first article dated 1946- $1947^{16}$ the author's wide knowledge of this field can be noticed as well as the firm standpoint that its laws "will undoubtedly play a significant role in the real and true creativity." The characteristic of all later articles of Milan Zloković is perceived in it: the tendency not to repeat oneself and not only to make the sections across the known theories, but immediately to test the application of the acquired knowledge in practice on the exact example, explaining the methods and the selected proportioning system. The reviews of the historically known methods are always brief and not rarely with the original contribution of the author associated with the method of composition and its origin, however, always with the emphasis on the significance which that method could have for the contemporary creator. Each work is characterized by the excellent knowledge and handling the mathematical proofs "although they were not popular in the circles of the architects" ${ }^{\prime 17}$.

In the introduction to many of his later works Zloković noted that the golden section had the preference over all other proportions given that "it possesses the widest range, allows for the infinite number of perfectly chained up combinations and - by controlling the intuitive postulate of the assumed relations - regulates their final values." That standpoint was arguments supported and widely elaborated by him in the article devoted 
to the significance of the golden section in the architectural composition in 1955 , and in the later publications the same standpoint was substantiated by the new examples from the past or by his own examples of application of the methods of the past to the modern architecture. The preference was given to a system only after the exhaustive analyses, interpretations in the form of proportional geometrical schemes or numerical tables. The preference was given to the golden section, namely to the uninterrupted section, followed only after the studies and comparisons made and a series of other proportional systems, actually all the known ones at that time. Thereby he was of an opinion that the proportional entity has to leave the liberty to the architect, automatically contesting the major argument of the opponents of application of the science on proportions in the art. The goal was the conformation of the parts with the entity, the harmony which can only be achieved by the knowledge of the science of proportioning "like the good knowledge of the science on harmony precedes categorically the skill of composing."18

Zloković insisted that each analyzed building had to be measured exclusively by the measuring unit it had been designed and built in. ${ }^{19}$ This standpoint was underlined by Zloković in all his works in respect to the system of measures and proportions of the architecture of the past.

All his actions were systematically explained by him, and he even clarified to the reader also which contemplations the compositional procedure in modular design was subjected to and which factors had the primary aesthetic and functional character and which ones the secondary. The primary ones are basically the axial space, on the façade the storey height and the relation of the mass between two openings to the width of the very opening, whereas all other internal measures were of secondary character. ${ }^{20}$

The major methods in presentation of the proportional key of a building in Zloković's analysis were systematically presented and clarified by the author himself in certain texts: "Proportional relations may be expressed in two specified manners:

a_by writing down the calculated modular values in the form of rational number or

$b_{-}$by making geometrical moves which indicate to the connection of certain parts with the entity."

(...) "By grouping both manners I wished to emphasize the correlation existing between the geometrical move and modular numbers which correspond to those moves." ${ }^{21}$ By such division into sections, by parallel, namely dual analysis, 
Zloković discovered the key for decoding the system of proportioning of any building based on some of the proportional systems of the past. Moving a step further, Zloković provided the proofs on the existence of the association of several systems in the same example, which among the theoreticians of proportions was often deemed unacceptable. ${ }^{22}$ In the example of the gate of Saint-Denis in Paris the compositional schemes show a harmonious modular connection, the principle of squaring, modular numbers of the F system (and their analogous presentation in the $\Phi$ system), explaining along the mutual link of these systems in geometry. (Fig. 3). In this example Zloković systematically and clearly presented the manner in which he approached the analysis of the proportional systems, making digressions which relate to the characteristics of the individual systems.

The question posed to himself regarding which of these two manners was better for placing the compositional scheme was answered by Zloković in his conclusion: "I am convinced, given the experience possessed in respect to direct applications of proportional systems in the modern design, that the answer should be in favor of the graphic method, providing that the control of measuring relations arising from the proportional diagrams, is to be done by arithmetic. ${ }^{23}$

These methods are rarely seen together in other authors as well who at that time dealt with proportions. Zloković grouped several procedures together, sometimes also seemingly diverse, in order to finally make the provided solution substantiated by as many facts and arguments as possible.

\section{CLASSIFICATION OF THE BASIC PROPORTIONAL SYSTEM ACCORDING TO MILAN ZLOKOVIĆ}

Almost each historical epoch and the development of the study on proportions in it, comprises one specified proportional system that is predominant. Zloković concluded that the square is with certainty the starting figure for all systems used or in use in architecture ${ }^{24}$ :

I _ Proportioning on the basis of the rational numbers - Harmonious system

II_ More complex proportioning on the basis of the irrational (nonmeasurable) measuring numbers - geometrical methods. It is restricted in architecture (and in art in general) to three geometrical systems:

1 to the $\sqrt{2}$ system or «squaring» (floor area) (key figures: square or regular octagon). The use of this system is characteristic for Gothic architecture or art; 
2 to the $\sqrt{3}$ system or «triangulature» (key figures: square, equilateral triangle and regular hexagon). The use of this system is characteristic for Gothic architecture or art;

3 _t the $\Phi=(\sqrt{ } 5+1) / 2$ system or to the so-called «division as per the golden section» or to the system of» uninterrupted division» (key figures: square, regular pentagon, regular decagon). The use of this system is characteristic for the ancient Greece..$^{25}$ (within this system there is also the system $\sqrt{5}$ and $1 / \sqrt{ } 5$, having the same key figures).

Zloković opposed Ghyka's position that the use of two or all three proportional systems on the same building was not theoretically permissible. He quoted the authors who had also disputed it and emphasized that "in the ancient times certain irrational systems were never perceived independently one from another". ${ }^{26}$ The proof for that was found already in Zeising's finding which Zloković quoted: "All regular polygons of the accurate geometrical structure are in the direct relation to the golden section. It was Zeising who proved that from the rectangle 1: $\phi$ the sides of the regular polygons could be derived from 3, 4, 5, 6 and 10 sides, inscribed in the circle $r=1 .{ }^{\text {" } 27}$ It is known that each of the regular polygons is the representative of one of the irrational systems: $\sqrt{2}, \sqrt{3}$ or $\sqrt{5}$, therefore on the basis of Zeising's statement all of them are integrated also into the system $\Phi=(\sqrt{ } 5+1) / 2$ and mutually connected. (Fig. 4) (In the same diagram the side of the regular octagon was also constructed which can be inscribed into the same given circle $r=1$, typical for the system of squaring but which has not been specially accentuated). Presently, another irrational system of the plastic number $\rho=1,325$ can be added to this scheme, and which Zloković was not familiar with, and which was analyzed in detail only in 1994 by the English historian of architecture, Richard Padovan. ${ }^{28}$

Out of the above mentioned systems, Zlokovic favored the harmonious one, since actually this system provided rational (measurable) relations by means of which the irrational-non-measurable relations of other proportions could be expressed with approximate value. (Fig. 5). Thus also all irrational systems can be expressed through the system $\Phi$, and in the value of the system $\Phi$ into rational relations of numbers from the Fibonacci sequence $\mathrm{F}$.

In several diagrams Zloković presented the geometrical link of the rational and irrational systems (Fig. 6) and showed the calculation of the error threshold which a human eye cannot perceive. In that way he wished to confirm once more the already known method of transposition of irrational values of the system $\Phi$ into the relations of the rational values of the Fibonacci sequence..$^{29}$ 
He presented graphically and by calculations the imperceptibility of the difference between geometrically constructed schemes within the system $\Phi$ and their respective values presented by rational relations of two numbers, which do not exceed the threshold of error perceptibility by the human eye. The approximate values are obtained by the fractions in which the numerator and the denominator are the members of the Fibonacci sequence, F. Transposition of irrational values of the system $\Phi$ into the rational systems $F$, he summarized in the diagram from which, later on, he would easily, directly take the values for conversion of any proportional scheme from one system into another.

That Milan Zloković had always a critical attitude towards this task, without blindly relying upon the statements of the recognized authorities, and that he devoted himself to this field with great zeal, can clearly be seen in many of his works.

Most frequently quoted work of Matila Ghyka, Le Nombre d'or, has the entire chapter devoted to "the divine proportion" - La Divine proportion, based on the belief that Fra Luca Pacioli understood the golden section under that term. It is interesting that such incorrectness was not noticed by Matila Ghyka, a superb mathematician, even though like Zloković as well, he personally had this work in his hands. In many of his works, Zloković relied on the works of Ghyka, highly renowned and often quoted within the field of proportions, so it is possible that for that reason by mistake he equaled the term of the golden section and the divine proportion in his early work, like many authors before him had also done so. ${ }^{30}$ However, on the occasion of his first encounter with the original manuscript of Luca Pacioli in Milan in $1955,{ }^{31}$ he himself was dissuaded that such statement was untrue, approaching the study of the work in his analytical, insightful manner and later on correcting the error in the text: „Divina proportion $\neq$ sezione aurea“32 Zloković concluded that actually Pacioli
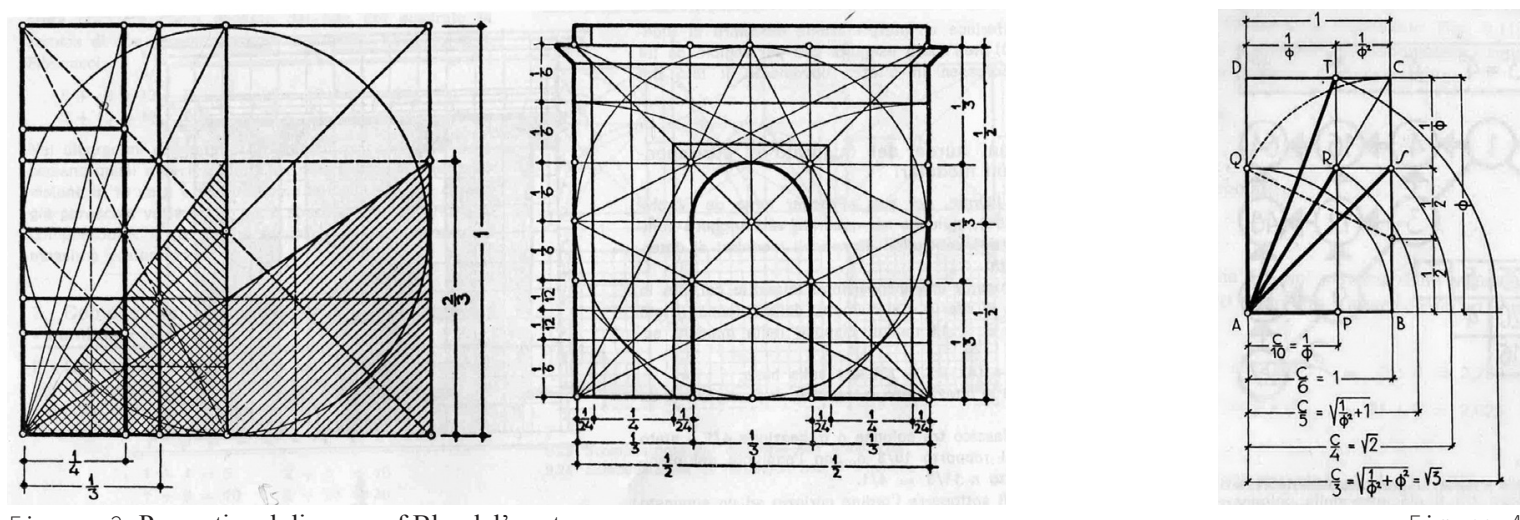

Figure 3 Proportional diagram of Blondel's gate 
in his drawings proposed the system of triangulature, because at that time the equilateral triangle was attributed greater significance than to the other geometrical figures. Although it is not for sure that it was Zloković who first arrived to this conclusion (many authors even later maintained this false belief), with this comment he expressed his profound dedication and critical approach to science, not leaving any statement unverified.

Le Corbusier in Ka pravoj arhitekturi (Towards the Real Architecture), as the direction one should follow in the procedure of application of proportions, quoted the proportional diagrams of Parthenon and Greek temples, and as the example of application of the same principles in the modern design provided the drawings of his own designs. However, Zloković noticed that Corbusier in his examples "deviated from the methods according to which classic proportional diagrams were conceived and which he presented in his book", as in the examples (mainly facades) the principles of analogy were applied, the methods of drawing the diagonal lines", which was presented by August Thierch already in $1885 .{ }^{33}$

With this observation Zloković confirmed his earlier statement in an unimposing manner: that he was a good architect who relied on his eye, favorably disposed towards proportion according to the uninterrupted division than to another system, however, also a simple graphic method of analogy could be added here, which the artist like Corbusier easily recognized as a compositional method of the great works of the past, like Michelangelo's. On the other side, according to him, unfavorably disposed towards the mathematical approach, Corbusier instinctively adopted and judged in favor of the above mentioned systems, more by the instinct, than by providing a convincing explanation.

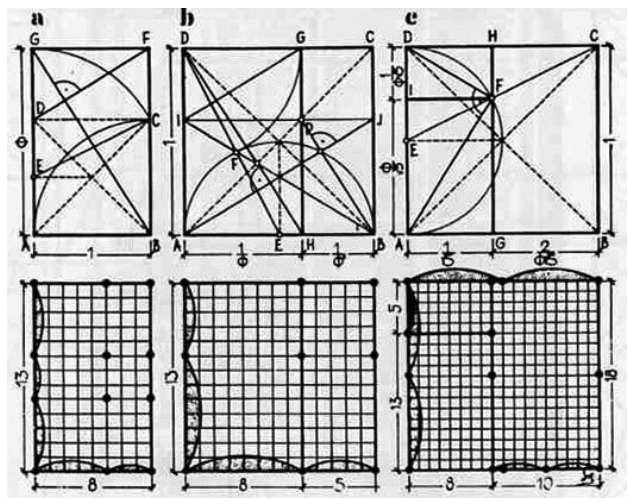

Figure 5

Non-harmonious breaking down of the square.

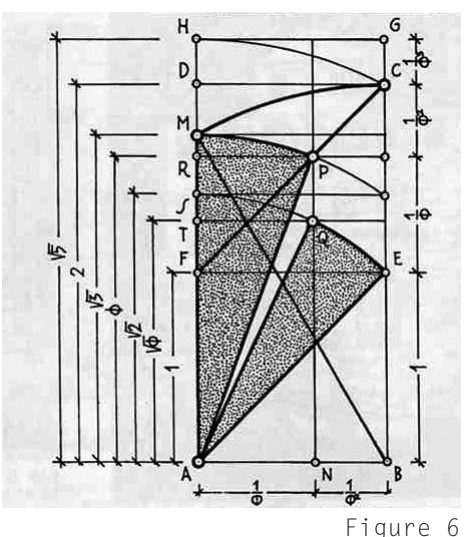

Diagram of the mutual link of irrational systems 
He contributed with the new proofs to the theory that the system of proportioning according to the golden section emerged in the works of the talented authors who in their design relied on their intuition. Unlike the system of continuous division, he considered $\sqrt{2}$ i $\sqrt{3}$ systems as rigid: "A good architect, used to composing "by playing by the ear" or "approximately", will rarely fall into the field of $\sqrt{2} i \sqrt{ } 3$ systems. In that respect it should be noted that these two systems, which are otherwise strictly subjected to geometrical speculations, are essentially monotonous, insufficiently flexible, and sometimes overly rigid." ${ }^{4}$

Through history of proportions the prime numbers were attractive as basically they were like basic notes in music. The most significant thing in respect to the prime numbers is that each integer can be written as the product of the prime numbers in a unique way, which is the fundamental theorem in mathematics. ${ }^{35}$ The prime numbers in mathematics are that which the basic harmonicas are in music, or basic colors in painting art. For that reason they have been much studied. Zloković was aware of the significance of the prime numbers, however he considered that, although this theme had been much researched, an acceptable solution of which set of prime numbers to be taken for preferential coefficients of the basic builder module still had not been provided. The study of this problem required the reconsideration of Plato's Lambda, harmonious consonant intervals, geometrical and recurrent traces. All these sets consisted of the defined combinations of predominantly prime numbers and therefore it was not rare that they had many common members. Their combination and in certain cases also the correspondence was only seemingly easily solvable problem. "Geometrical progressions with the quotient 2 and 3, based on Plato's dual tetractys (Lambda) 1,2,4,8 and 1,3,9 and 27 were integrated without any difference in all proposals, solve the problem only partially". ${ }^{36}$ Their application in architecture requires the most favorable combination which would provide the architect with the liberty by sufficient number of available elements (products of multiplication of the main design module, eg. $M=60 \mathrm{~cm}$ ), however, avoiding also the excessive number of combinations whereby the practical sense of the application of such set would be lost. Milan Zloković himself experimented with the system of Plato's Lambda (crossing two or more geometrical progressions) which are contained in the sequences with factors 2,3,5, then with 2, 3,4,5 and finally with 2,3,5,6.(Figures 7 and 8).

In the final conclusions following years of researches within the theory of proportions and modular coordination, Zloković's definite standpoint was that octametric system possessed great preference over the metric one as more suitable in building industry due to its anthropomorphic characteristics. By 
adopting the module $\mathrm{M}=12 \mathrm{~cm}$ within this system, the decimal division would not be cancelled completely, but would be secondary, so that the metric system as well would continue to be contained within the octametric one. Depending on the type of design, the design module representing the integer product of multiplication of the basic module regulating the density of the modular network is adopted (e.g. $6 \mathrm{M}=\mathrm{M} 6=75 \mathrm{~cm}$, za M=10cm).

Zloković emphasized that the proposal of application of the ocatmetric system as the most suitable one was first provided by Ernst Neufert $\mathrm{u}$ Bauordnungslehre (BOL) already in 1936, Within the field of modular coordination, Zloković in many aspects had especially close standpoints to Neufert's rather than Corbusier's ones.

Zlokovićs practical advice: "that the present manner of leveling should be replaced by a new one and the levels in designs to be entered exclusively in modules (in unnamed modular numbers), and the understanding at the construction site to be effected by module-metric scale rule divided into three differently accentuated divisions such as: $1 M 10=10 x M=20 x M / 2$ $=50 x M / 5^{637}$ (i.e. $125 \mathrm{~cm}, 10 \times 12.5 \mathrm{~cm}, 20 \times 6.25 \mathrm{~cm}$ i $50 \times 2.5 \mathrm{~cm}$ ). In another text Zloković stated that his design of the Teachers Training School in Prizren (in collaboration with Arch. Đorđe Zloković and Arch. Milica Mojović), was executed according to the drawings having such manner of leveling and emphasized that the contractors at the construction site had not the least dilemmas to interpret them during construction and thus confirmed its correctness.

THE SUMMARIZED SURVEY OF THE ORIGINAL CONTRIBUTION OF MILAN ZLOKOVIĆ IN THE THEORY OF ARCHITECTURAL COMPOSITION

Out of the complete work of Milan Zloković on proportions several concrete findings can be singled out as his personal contribution to the field of proportions in architecture:

In the study of the proportional set of Vignola's style orders dating 1953/56, Zloković did not take the column radius as the starting unit namely module, like Vigniola himself had done, but the axial space/span of the columns, using the relative space/span for each order individually. Vignola, most likely, as was generally accepted in the Renaissance, accepted unreservedly the definition of the column radius as the starting module, as per Vitruvius. Zloković was not the first one to take the axial space/span of the columns as the modular unit at 
proportional analysis of the monuments of the past, ${ }^{38}$ however, by applying this starting point he arrived to the new discovery, undoubtedly an original one. With the starting assumption that the axial space/span was the module for geometrical proportional analysis of Vignola's orders, it was for the first time proved that all four orders, the Toscanian, the Doric, the Ionian and the Corinthian order, with some slight changes in dimensions, fit into geometrical schemes based on the golden section. Applying this method on the occasion of the proportional analysis of Vignola's orders. Zloković's goal was to confirm one of his earlier statements: that the law of the uninterrupted division or "golden section" was the only proportional system which any creatively gifted man intuitively aspired to. Vignola had not known the system of the uninterrupted division and in an empirical manner he adopted the relations defining each order. These modular numbers were revised by Zloković in accordance with his new greater unit module and the proportional relations were expressed in two above mentioned methods: leveling in the modular measures and making geometrical moves which indicate to the proportional link of certain parts with the entity. ${ }^{39}$ (Figures 9 and 10)

One of maybe most interesting discoveries of Milan Zloković is the eleventh type of irrational proportion which is a continuation of the ten classic irrational types which were defined by Pythagoreans and the New Pythagoreans by the first century B.C., deriving them from the formula for the uninterrupted geometrical proportion $\mathrm{a} / \mathrm{b}=\mathrm{b} / \mathrm{c}$. In his book Nombre d'or, Matila Ghyka described them from the mathematical point of view. It is interesting that given that he himself was an excellent mathematician, Matila Ghyka did not notice that the number of types was not infinite, namely that the potential of the initial formula which all types had been derived from $(\mathrm{a} / \mathrm{b}=\mathrm{b} / \mathrm{c})$, had not been exhausted till the end. For quite long time the number ten had a significant place, primarily a symbolic one, in the learning of the Pythagoreans, ${ }^{40}$ and was further rather appreciated with the modern authors as well, and maybe that is one of the reasons why he and nor the other authorities from within this field

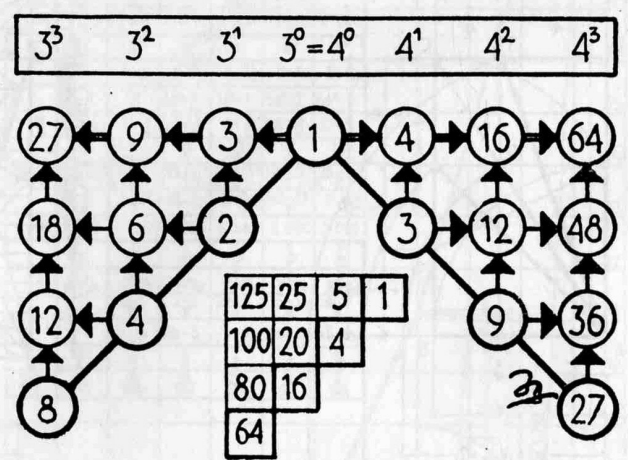

Figure 7 Plato's Lambda

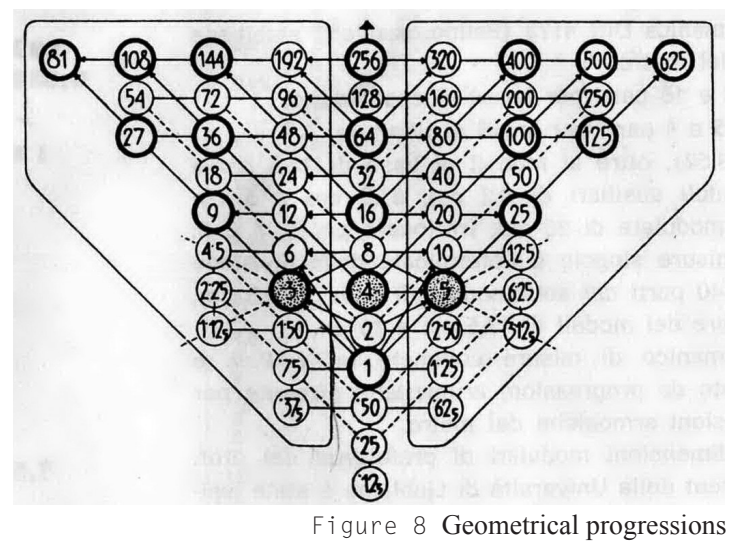


had not paid the attention to the incompleteness of typology. For the first time Milan Zloković mentioned in a discreet manner this discovery of his in only one sentence in the text: Sur le choix d'une gamme dimensionelle dans la coordination modulaire en architecture" dated 1957. This example affirms Zloković's systematic approach and dedication to the problem of proportions, never neglecting the experience of the past, nor leaving them unverified and unanalyzed once more in his own way, in order to confirm or dispute their significance.

In the comprehensive study dated 1957, "On the role and significance of the proportional compasses in compositional methods of the ancient visual art" 41 it was for the first time in the science that the possible manner of using the asymmetric proportional compasses was interpreted. Geometrical relations of compasses were based on "the square or aesthetic proportion" and were defined depending on the relation of compasses legs length. Zloković's proposal was preceded by a detailed analysis of the proportions used in the ancient world. Apart from explaining geometrical relations which was made possible for him by the six known to him, discovered compasses dating from the times of the Ancient Greece and Rome, Zloković even provided the tabular survey of the possible combinations of compasses which maybe one day would only be discovered by the archeologists. With schematic surveys he explained the practical manner in which the ancient builders applied this tool, which again confirms that Zloković's approach to the problem of proportions was always closely and indirectly associated with the wish that the result and conclusion of the research be a practical, technical instrument, by means of which a technical facilitation would be introduced into architectural composition, and not the mystification and introduction of the symbols as elements. (Figures 11).

In 1960, Zloković published his paper Integrating the "Modulor" in the Iinternational Modular System, in which maybe for the first time, one architect provided a concrete proposal how to overcome the problem of fractioned numbers

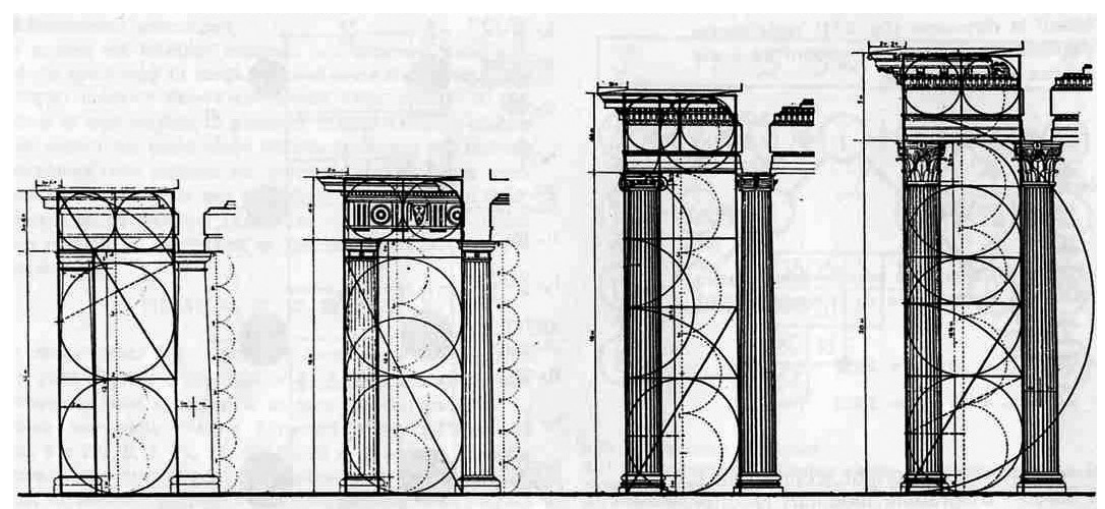


of the famous Corbusier's blue and red sequence for the metric measuring system. In both sequences Corbusier provided integer values of the members but only in the British foot-inch system. However, when wishing to convert these measures from foot inch system into the European, metric system, they became irrational measures, wishing to directly correspond to the sequences for the British system of measures. Le Corbusier's goal was with the red and the bleu sequences to reconcile the differences existing between the British and the European system of measures, in such way that these sequences would represent the sets of preferential numbers which the modules would be multiplied by, i.e. the unit measures of the metric and foot-inch system: in the metric system $1 \mathrm{M}=10 \mathrm{~cm}$, in foot-inch system $1 \mathrm{M}^{\prime}=4$ " (which is approximately equal to $10.16 \mathrm{~cm}$, however, according to the international agreement it was equaled with $1 \mathrm{M}=10 \mathrm{~cm}$ ). Modulor, on the basis of Le Corrbusier's statements, represents the scale of universal measures mutually linked by the golden section, and thereby with the adequate measures of the human body (anthropomorphic). He achieved that by using the members of the Fibonacci sequence for the red and the bleu sequence given that the two adjoining members in the Fibonacci sequence stand in relation close to the golden section. He adopted them for the members of the blue sequence: 123581321345589144 . Half of these values were taken by him for the red sequence, given that half of 144 gives a preferential number 72 , multiplied by one inch the average height of the man is obtained which Le Corbusier took for the key value. By proportional chaining up based on the golden section, from this key measure other measures of the human body are obtained. However, the preferential numbers provided corresponding values only in the British system. In the European metric system, in order to obtain the same values for the height of the man and the other measures which follow thereafter, the preferential numbers had to be recalculated and it was no way possible to obtain integer values, but the ones rounded to two decimals. In order for the final measure, i.e. the product of the module and preferential number of the red or the blue sequence to be equal both for the manufacturer

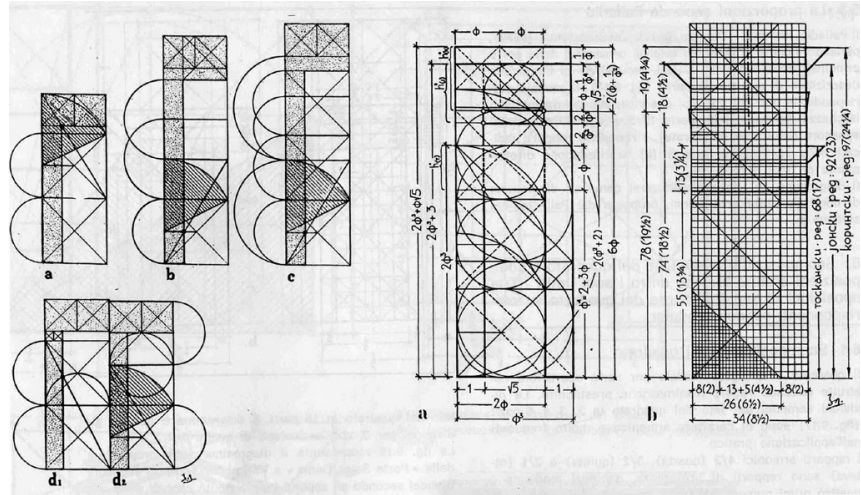

Figure 10

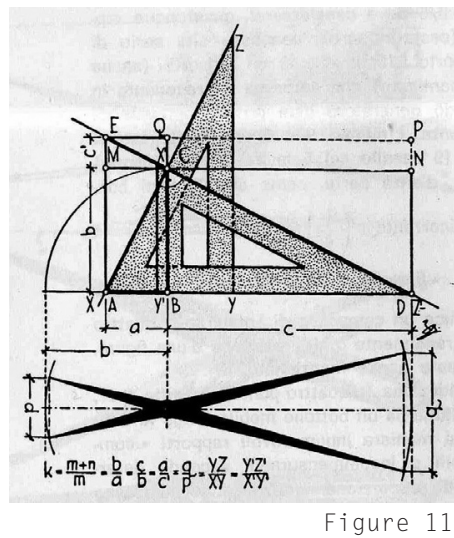

Modulor and the new recurrent sequence 
in England and the one in some other European country, Corbusier sacrificed the preferential numbers of the metric system, by simple recalculation of the values from the sequence adopted for foot-inch system, leaving it irrational.

Zloković, not elaborating on this occasion the problem of difference between the modules $\mathrm{M}$ and $\mathrm{M}$ ', set by the International Bureau of Standardization, solved ultimately the problem defined by Le Corbusier: provide whole preferential numbers in the red and the blue sequences also for the metric system as provided for the foot-inch system.

Adhering to the guiding idea of Le Corbusier that the value of the numbers in sequence be in relation of the golden section, and thus achieve the system chained by the uninterrupted division, and at that anthropomorphic as well, Zloković offered the set of numbers which should be applied for the red and the bleu sequences in the metric system, expressed by integers. Knowing the substance of the Fibonacci sequence, that it was the first recurrent sequence in mathematics ${ }^{42}$, he sought which recurrent sequence contained the number 18 , which when multiplied by $\mathrm{M}=10 \mathrm{~cm}$ would provide the height of the man as the key value of Corbusier's system. Zloković discovered already in the second recurrent sequence the set of preferential numbers for the red sequence: 134 71118 and its double values 2681422 , for the blue sequence. That way he preserved the principle of proportional division. (Figures 12 and 13).

According to Đorđe Zlokovića, Milan Zloković's son, his father sent this proposal to Le Corbusier, however has not received any reply.

In his last paper Coordinazione modulare, Zloković presented the comment that he was the first to see the concurrence of the contemporary international module of $10 \mathrm{~cm}$ and the module integrated into the Egyptian ancient anthropomorphous network. The Ancient Egyptian canon contained the fist as the unit.

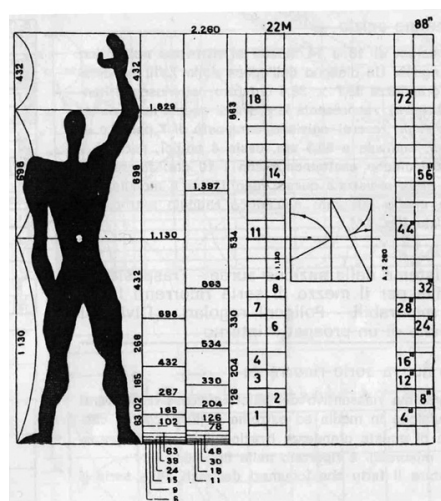

Figure 12

Replacement of the compasses scales

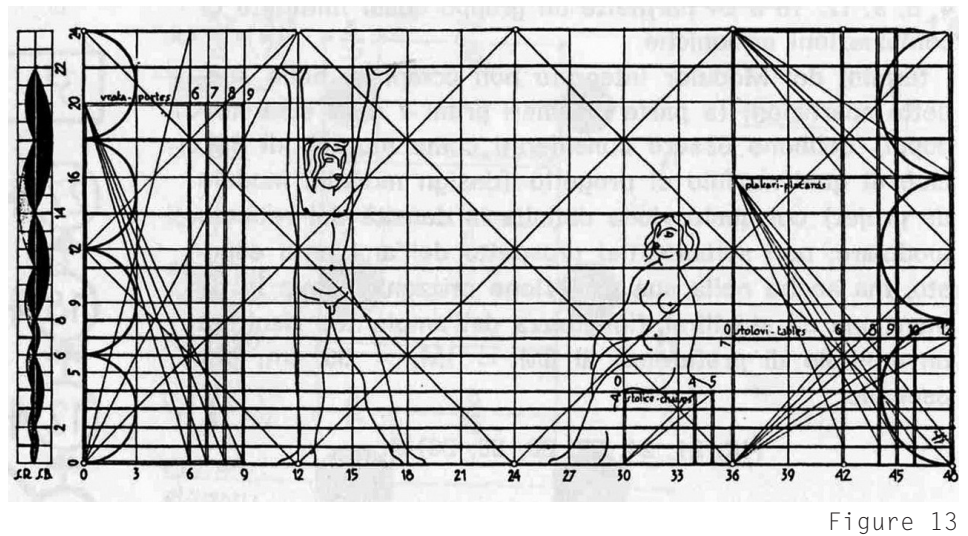

Proportional diagrams of Toscana, Ionic and Corinthian 


\section{THE FIRST INTERNATIONAL CONGRESS ON PROPORTIONS}

\section{IN MILAN IN 1951}

In 1955 Zloković wrote: "The real and practical lessons based on the simple numerical relations between certain levels have their deep root in compositional methods of the past. They have not been discussed to a sufficient extent for the reason that it was believed they had no substantial significance, even when it was known that they existed. Even still today the skepticism exists in respect to the studies from this neglected field, so substantial for proper understanding of the conceptual essence of the compositional procedure. The interest in the problems of this type has started to stir in the interested circles of the global public" ${ }^{43} \mathrm{He}$ mentioned the First International Congress on Proportion in the Arts within the "IX Triennale" in Milan, in 1951, as the outstanding example of this interest. Unfortunately, the conclusions of this Congress did not contribute to the popularization of this theme among the architects and the experts, but, on the contrary, affirmed the irreconcilableness of the biased standpoints. ${ }^{44}$ The three-days long Congress brought together the intellectuals from within several areas of architecture (Matila Ghyka, Rudolf Wittkower, James Ackerman, Sigfried Giedion, Pier Luigi Nervi, Bruno Zevi, Le Corbusier), the academicians, experts, design architects and designers, speaking different languages with the goal that each one should respond to the topic in his own way. However, instead of marking the renaissance of science on proportions in architecture, the participants did not succeed in reaching an understanding. According to some of them that was the problem of the beautiful of the architecture of the past which presently was no longer of substantial significance as other problems become imposed and more doubts than the integrated conclusion came to light. And the Congress was concluded even without the usual publication.

Among the participants at the Congress who supported the popularization of proportions, except for Le Corbusier who presented his Modular, there were no individuals who like Zloković were engaged in this theme with the strict geometrical-mathematical approach, with firm arguments and proofs in their favor.

\section{CONCLUSION}

The scientific work of the architect and professor Milan Zloković was orientated in the direction of objectivization of the designer procedure, rational and controlled method in the manner of design, as the result of his own creative experience. By his systematic research, he emphasized in order the significance 
of certain methods in the manner of designing from the past, and then broke down and classified each individual method or theory into certain entities, not according to the historical context, but according to the determined significance for the modern compositional method. Zloković considered the measure and number in architectural composition crucial for achieving the harmony on some building and the conformity of the past with the entity. He studied all known proportional systems of the past in order to accurately determine the significance of each one for the contemporary creator. In his profound dedication to solving this problem, it seems that Zloković even engaged into purely mathematical discussions, but only in order to demonstrate that by studying the science on integers, sets of preferential numbers and proportional systems, Zloković wanted to widely perceive the problem matter and provide the most objective conclusion of validity of each method of proportioning taken into consideration. His conclusions and results of the researches were most often expressed by him in the form of tables, diagrams or geometrical drawing. The number and the geometrical figure are the methods by means of which he presented the objective opinion for each of the analyzed systems. The research of the contemporary methods in architectural composition was continued also by Zloković's work on modular coordination in the industrial prefabrication. In numerous publications, by representing Serbia in this field at congresses abroad, by participating at the consultations and lectures, Zlokovic took a significant place in this science. He considered himself to be the follower of the ideas of Le Corbusier and L. Neufert, however, he managed to make also his personal contribution within the field of compositional methods in design. Successful liaison of the theory and practice within the field of proportions was characteristic to a small number of architects of the modern movement. Which again accentuates the significance of the work of the architect Milan Zlokovic in the complex field of proportions and coordinated modulation in architecture.

Brkić, Aleksej. Znakovi u kamenu, Srpska moderna arhitektura 1930-1980, Savez arhitekata Srbije, Beograd, 1992, p.108 mera u arhitektonskom projektovanju, „Tehnika“, No. 2, 1954, p.176 ( given that he himself has been integrated in that system, Milan Zlokovic, On the Problem of Modular Coordination of Measures in Architecture 
Monier, Gérard. L'architecture en France, une histoire critique 1918-1950. Architecture, culture, modernité, Paris, Philippe Sers / Vilo, 1990

Kruft, Hanno-Walter. A history of architectural theory, London: Zwemmer; New York: Princeton Architectural Press, 1994. p. 402.

Zapažanja (perceptions) Miloš Perović, Ljiljana Blagojević, Vanja Panić; Zgrada Fiata, Škola u Jagodini, Trgovinsko-industrijska komora u Skoplju (The FIAT Building, the School in Jagodina, The Commercial-Industrial Chamber in Skopje)

Schumacher, Thomas. Il Danteum di Terragni: 1938, officina, Roma, 1980

Silvia Danesi, Cesare Cattaneo, neoplatonismo nell'architettura razionale del Gruppo di Como, "Lotus", No.16, 1977

Cattaneo, Cesare. $\pi$ e $\varphi$, „Casabella“, maggio 1942, No.173, pp. 21-23

It was only in the last chapter of Modulor that Corbusier published the correspondence with the mathematician R. Taron, who sent him the proof of the error in Corbusier's hypothesis dated 1942: " take two equal and bordering squares and place the third square at the place known as the place of the right angle." And actually the two initial squares are not squares due to the difference of two sides by six thousandth portion. Corbusier was aware that the difference was insignificant to the eye however that in philosophy it had an infinite value, "...And it is that which sets us in motion." Concluded Corbusier, Modulor, Niksic, 2002.

Zloković, Milan. Uticaj recipročnog zalančavanja harmonijskih razmera na proporcijski sklop izvesnog fasadnog sistema, „Tehnika“Nos. 6 and 7, 1954, pp. 833-840 and 1001-1006.

Zloković, Milan. Uloga neprekidne podele ili "Zlatnog preseka” u arhitektonskoj kompoziciji. „Pregled Arhitekture“, Beograd, Issues 1 and 2, 1954, issue 3,1955, p.12.(The Role of the Uinterrupted section or "Golden section» in Architectural Compoistion)

Zloković, Milan. Uloga neprekidne podele ili "Zlatnog preseka” u arhitektonskoj kompoziciji. „Pregled Arhitekture“, Beograd, Issues 1 and 2, 1954, Issue 3,1955,p.85

Philibert Delorme (1515-1570) and George Jouven from the beginning of the 20th century, Zloković indicated as the architects who during their time understood the significance of measuring a building by the system of measures in use during the construction.

Zloković, Milan. Kritički osvrt na modularne mere standardnih elemenata "Durisol" putem analize dve fasadne kombinacije u oktametarskom sistemu, Tehnika, no.3/1955, Beograd, p.333 (T61) (Critical review of the modular measure of the standard elements «Durisol» by analyzing two facade combinations in octometric system)

Zloković, Milan. Uticaj proporcijskog sistema Blondelove kapije Sv. Denija u Parizu na nedovoljno rasvetljeni problem proporcija u arhitekturi, "Godišnjak Tehničkog fakulteta Univerziteta u Beogradu 1946- 1947”, Beograd, 1949, pp. 45-46 (The influence of the proportional system of Blondel's gate of Saint- Denis in Paris upon insufficiently clarified problem of proportioning in architecture)

Ghyka, C. Matila. Le nombre d'Or. Rites et Rythmes dans le développement de la civilisation occidentale, Gallimard, Pariz 1959.

Zloković, Milan. Uticaj proporcijskog sistema Blondelove kapije Sv. Denija u Parizu na nedovoljno rasvetljeni problem proporcija u arhitekturi, "Godišnjak Tehničkog fakulteta Univerziteta u Beogradu 1946- 1947”, Beograd, 1949, p. 54

Zloković, Milan. La coordinazione modulare, u "Industrializzazione dell'edilizia", Istituto di Architettura della Facoltà di Ingegneria, Università degli Studi di Bari, Bari 1965, pp. 140-196.

In his article Anthropomorphic systems of measures in architecture, Zloković explains that the right-angled triangle of $30^{\circ}$ and equilateral triangle of $45^{\circ}$ which actually represent the means for proportioning as per the irrational systems $\sqrt{2}$ and $\sqrt{3}$, given that one is the half of the square, the key figure of the system $\sqrt{ } 2$, and the other one the half of the equilateral triangle, the key figure of the system $\sqrt{ } 3$.

Zloković Milan. The influence of the modular coordination upon the aesthetic component in architecture, Federal bureau for the productivity of work (Consultations on modular coordination in architecture), Belgrade 1958, p. 11. 
Zloković, Milan. Uticaj proporcijskog sistema Blondelove kapije Sv. Denija u Parizu na nedovoljno rasvetljeni problem proporcija $u$ arhitekturi, "Godišnjak Tehničkog fakulteta Univerziteta u Beogradu 1946- 1947”, Beograd, 1949, ptr.56

Proportioning on the basis of the irrational numbers can presently be added to with a so-called Plastic number $\rho=1.324718$.....Plastic number is yet another irrational number which can be presented by a geometrical relation and used as the system of proportioning. The first to describe it and use it for that purpose was the Dutch priest Van der Laan (1904-1991) as early as in 1924, and later on presented in detail in the book „Le nombre plastique”, by E. J. Brill, Leiden, in 1960, but was only more widely noticed after publishing the study by Richard Padovan „Dom Hans van der Laan: Modern Primitive", Architectura \& Natura Press, Amsterdam ,1994. In his book R. Padovan also stated the plastic number as yet another proportional system which is also directly connected to the other irrational systems

Owing to transposition of $\Phi$ into $F$ system, it is easy to establish also the connection between the harmonious system and the system of the golden section: the sides of the square by simple geometrical moves can be divided into the parts which are in relations represented by the prime numbers - harmonious consonant intervals (harmonious relations form the music art) 1:1, 5:4, 4:3, $3: 2,5: 3,2: 1$ and vice versa. The numbers $1,2,3$ and 5 coincide with the first four members of the Fibonacci sequence, which makes geometrical display on the same diagram possible.

This false belief lasted for quite long time, from the end of the $15^{\text {th }}$ century till mid $20^{\text {th }}$ century, maybe exactly owing to the authorities from within the field of proportions, who for long time had presented it as a fact.

Courtesy of Professor Muzio (Giovanni Muzio) in his private library, Zloković studied the original work of Pacioli , published in 1509., Zloković, Milan. Divina proportion $\neq$ sectio aurea, "Pregled arhitekture", issue 4-5, Belograd, 1956, p. 93

Zloković, Milan. O problemu modularne koordinacije mera u arhitektonskom projektovanju, „Tehnika“, no. 2, 1954, p.176

Another curiosity is that the only even prime number, is the number 2. Like any tone can be "broken" into the summary of the basic harmonies, or like each color is the proportional mix of red, green and blue. There are many statements related to the prime numbers (many still unproved), since the time of Pythagoras. With the ancient Greeks there was a connection among mathematics, music and the spirit

Zloković, Milan. Uticaj modularne koordinacije na estetsku komponentu u arhitekturi, Savezni zavod za produktivnost rada (Savetovanje o modularnoj koordinaciji u građevinarstvu), Beograd, 1958 , p. 8

Zloković, Milan. O problemu modularne koordinacije mera u arhitektonskom projektovanju, „Tehnika“, no. 2, 1954, p.182

Zloković, Milan. Antropomorfni sistemi mera u arhitekturi, "Zbornik zaštite spomenika kulture", volumes 4-5, Beograd, 1955,pp. 181-216

Zloković, Milan. Geometrijska analiza proporcijskog sklopa arhitektonskih redova po Vinjoli, „Zbornik Arhitektonskog fakulteta“, volume 2, Arhitektonski fakultet Univerziteta u Beogradu, Belgrado, 1956, pp. 35-73.

Ghyka, C. Matila. Le nombre d'Or. Rites et Rythmes dans le développement de la civilisation occidentale, Gallimard, Pariz 1959.

Filozofija i mistika broja, Književna Zajednica Novog Sada, Novi Sad,1987

Zloković, Milan. Za ulogata i značenjeto na proporcionite šestari vo kompoziciskite metodi na antičkata likovna umetnost, Zbornik Tehničkog fakulteta u Skoplju 1957/1958 (published in 1960.) Zloković, Milan. Integrisanje modulora u Internacionalni modularni sistem, ArhitekturaUrbanizam 6/1960, Beograd

Recurrent sequence is the sequence of numbers in which the sum of two preceding members gives the following one. For the first two members any natural numbers may be taken, so that there are infinitely many recurrent sequences. The first four sequences with the initial members 
$(1,1),(1,2),(1,3)$ and $(1,4)$, all without exception by the relation of the two adjoining members aspiring to the division as per golden section $\Phi=1,618 \ldots$

Zloković, Milan. Antropomorfni sistemi mera u arhitekturi, "Zbornik zaštite spomenika kulture", volumes 4-5, Beograd, 1955, p. 182

Fulvio Irace, Anna Chiara Cimoli, La divina proporzione. Triennale 1951, Electa, Milano, 2007

Zloković, Milan. Uticaj proporcijskog sistema Blondelove kapije Sv. Denija u Parizu na nedovoljno rasvetljeni problem proporcija u arhitekturi, "Godišnjak Tehničkog fakulteta Univerziteta u Beogradu 1946- 1947”, Beograd, 1949, pp. 45-57.

Zloković, Milan. O problemu modularne koordinacije mera u arhitektonskom projektovanju, „Tehnika“, Issue No. 2, 1954, pp.169-182

Zloković, Milan. Uticaj recipročnog zalančavanja harmonijskih razmera na proporcijski sklop izvesnog fasadnog sistema, „Tehnika“ Issues Nos. 6 i 7, 1954, pp. 833-840 and 1001-1006.

Zloković, Milan. Uloga neprekidne podele ili "Zlatnog preseka" u arhitektonskoj kompoziciji. „Pregled Arhitekture“, Beograd, issues 1 and 2, 1954, pp.44-48 and pp.11-17, issue 3,1955, pp.80-85.

Zloković, Milan. Antropomorfni sistemi mera u arhitekturi, "Zbornik zaštite spomenika kulture", volumes 4-5, Beograd, 1955, pp. 181-216

Zloković, Milan. Kritički osvrt na modularne mere standardnih elemenata "Durisol" putem analize dve fasadne kombinacije u oktametarskom sistemu, Tehnika, Issue.3/1955, Beograd

Zloković, Milan. Divina proportion $\neq$ sectio aurea, "Pregled arhitekture", issue 4-5, Belograd, 1956, pp. 93-95 
Zloković, Milan. Geometrijska analiza proporcijskog sklopa arhitektonskih redova po Vinjoli, „Zbornik Arhitektonskog fakulteta“, volume 2, Arhitektonski fakultet Univerziteta u Beogradu, Belgrado, 1956, pp. 35-73.

Zloković, Milan. Uticaj modularne koordinacije na estetsku komponentu u arhitekturi, Savezni zavod za produktivnost (Savetovanje o modularnoj koordinaciji u građevinarstvu), Beograd, 1958

Zloković, Milan. Za ulogata i značenjeto na proporcionite šestari vo kompoziciskite metodi na antičkata likovna umetnost, Zbornik Tehničkog fakulteta u Skoplju 1957/1958 (published 1960.)

Zloković, Milan. Integrisanje modulora u Internacionalni modularni sistem, "ArhitekturaUrbanizam" 6/1960, Beograd

Zloković, Milan. La coordinazione modulare, u "Industrializzazione dell'edilizia", Istituto di Architettura della Facoltà di Ingegneria, Università degli Studi di Bari, Bari 1965, pp. 140-196.

Brkić, Aleksej. Znakovi u kamenu, Srpska moderna arhitektura 1930-1980, Savez arhitekata Srbije, Beograd, 1992.

Blagojević, Ljiljana. Modernism in Serbia: the Elusive Margins of Belgrade Architecture, 19191941 (Cambridge, Mass.: The MIT Press / Harvard University Graduate School of Design), 2003.

Cattaneo, Cesare. $\pi$ e $\varphi$, „Casabella“, maggio 1942, Issue.173, pp. 21-23

Fulvio Irace, Anna Chiara Cimoli, La divina proporzione. Triennale 1951, Electa, Milano, 2007

Ghyka, C. Matila. Le nombre d'Or. Rites et Rythmes dans le développement de la civilisation occidentale, Gallimard, Paris 1959.

Ghyka, C. Matila. Filozofija i mistika broja, Književna Zajednica Novog Sada, Novi Sad,1987

Kruft, Hanno-Walter. A history of architectural theory, London : Zwemmer ; New York : Princeton Architectural Press, 1994. p. 402.

Le Corbusier, Modulor, Nikšić, 2002

Le Corbusier, Edicija: Velike knjige arhitekture, Ka Pravoj Arhitekturi, Beograd, Građevinska knjiga, 2006.

Manević, Zoran. Zloković, Institut za istoriju umetnosti i Muzej savremene umetnosti, Belgrado 1989.

Milenković, Branislav. Rečnik modularne, Beograd, Arhitektonski fakultet Univerziteta u Beogradu, 1977

Monier, Gérard. L`architecture en France, une histoire critique 1918-1950. Architecture, culture, modernité, Paris, Philippe Sers / Vilo, 1990

Schumacher, Thomas. Il Danteum di Terragni: 1938, officina, Roma, 1980

Silvia Danesi, Cesare Cattaneo, neoplatonismo nell'architettura razionale del Gruppo di Como, "Lotus", issue 16, 1977 
Figure 1 The sector of façade layout obtained by application of Plato's Lambda and harmonious system (Source: Zloković, Milan. La coordinazione modulare, u "Industrializzazione dell'edilizia", Istituto di Architettura della Facoltà di Ingegneria, Università degli Studi di Bari, Bari 1965, p. 154)

Figure 2 Graphic display of gradual division of design module into 2, 3 and 5 equal parts of the module equal to $60 \mathrm{~cm}$ (Source: ibidem, p. 176)

Figure 3 Proportional diagram of Blondel's gate (Source: Zloković, Milan. Uticaj proporcijskog sistema Blondelove kapije Sv. Denija u Parizu na nedovoljno rasvetljeni problem proporcija u arhitekturi, “Godišnjak Tehničkog fakulteta Univerziteta u Beogradu 1946- 1947”, Beograd, 1949, p. 47)

Figure 4 Diagram of direct geometrical link of all regular polygons and the golden section (Source: Zloković, Milan. La coordinazione modulare, u "Industrializzazione dell'edilizia", Istituto di Architettura della Facoltà di Ingegneria, Università degli Studi di Bari, Bari 1965, p. 145) 
Figure 5 Non-harmonious breaking down of the square. Breaking down of the rectangle by means of Lambda (Source: ibidem, p. 153)

Figure 6 Diagram of the mutual link of irrational systems (Source: ibidem, p. 164)

Figure $7 \quad$ Plato's Lambda (Source: ibidem, p. 146)

Figure $8 \quad$ Geometrical progressions with the quotients 2 and 4 in vertical direction and with the quotients 3 and 5 in diagonal directions, based on Pythagorean triple number 3, 4, 5 (Source: Zloković, Milan. Uticaj modularne koordinacije na estetsku komponentu u arhitekturi, Savezni zavod za produktivnost (Savetovanje o modularnoj koordinaciji u građevinarstvu), Beograd, 1958, Fig.1)

Figure 9 Proportional diagrams of Vignola's orders in the system $\Phi$ (Source: Zloković, Milan. Geometrijska analiza proporcijskog sklopa arhitektonskih redova po Vinjoli, ,Zbornik Arhitektonskog fakulteta“, volume 2, Arhitektonski fakultet Univerziteta u Beogradu, Belgrado, 1956)

Figure 10 Proportional diagrams of Toscana, Ionic and Corinthian transposed into the systems $\mathrm{F}$ and $\Phi$ (Source: ibidem.)

Figure 11 Replacement of the compasses scales 8:5 and 9:5 with right-angle triangle the relations of the kathetes of which correspond to compasses scale. (Source: ibidem, Figure 7)

Figure 12 Modulor and the new recurrent sequence (Source: Zloković, Milan. Integrisanje modulora u Internacionalni modularni sistem, “Arhitektura-Urbanizam” 6/1960, Beograd)

Figure 13 Integrating the "Modulor" in the International Modular System: dimensions of the standing and seating human figure, demonstrated in the space divided vertically in 24 modules and horizontally in 48 modules (Source: ibidem Figure 16 - Zloković, Milan. Integrisanje modulora u Internacionalni modularni sistem, “Arhitektura-Urbanizam" 6/1960, Beograd 